\title{
Trends in normalized difference vegetation index (NDVI) associated with urban development in northern West Siberia
}

\author{
Igor Esau ${ }^{1}$, Victoria V. Miles ${ }^{1}$, Richard Davy ${ }^{1}$, Martin W. Miles ${ }^{2}$, and Anna Kurchatova ${ }^{3}$ \\ ${ }^{1}$ Nansen Environmental and Remote Sensing Centre/Bjerknes Centre for Climate Research, Bergen, Norway \\ ${ }^{2}$ Uni Research Climate/Bjerknes Centre for Climate Research, Bergen, Norway, Institute of Arctic and Alpine Research, \\ University of Colorado, Boulder, Colorado, USA \\ ${ }^{3}$ Institute of the Earth's Cryosphere, Tyumen Oil and Gas University, Tyumen, Russia \\ Correspondence to: Igor Esau (igor.ezau@ nersc.no)
}

Received: 17 January 2016 - Published in Atmos. Chem. Phys. Discuss.: 18 March 2016

Revised: 21 June 2016 - Accepted: 27 June 2016 - Published: 1 August 2016

\begin{abstract}
Exploration and exploitation of oil and gas reserves of northern West Siberia has promoted rapid industrialization and urban development in the region. This development leaves significant footprints on the sensitive northern environment, which is already stressed by the global warming. This study reports the region-wide changes in the vegetation cover as well as the corresponding changes in and around 28 selected urbanized areas. The study utilizes the normalized difference vegetation index (NDVI) from highresolution $(250 \mathrm{~m})$ MODIS data acquired for summer months (June through August) over 15 years (2000-2014). The results reveal the increase of NDVI (or "greening") over the northern (tundra and tundra-forest) part of the region. Simultaneously, the southern, forested part shows the widespread decrease of NDVI (or "browning"). These region-wide patterns are, however, highly fragmented. The statistically significant NDVI trends occupy only a small fraction of the region. Urbanization destroys the vegetation cover within the developed areas and at about 5-10 km distance around them. The studied urbanized areas have the NDVI values by 15 to $45 \%$ lower than the corresponding areas at $20-40 \mathrm{~km}$ distance. The largest NDVI reduction is typical for the newly developed areas, whereas the older areas show recovery of the vegetation cover. The study reveals a robust indication of the accelerated greening near the older urban areas. Many Siberian cities become greener even against the wider browning trends at their background. Literature discussion suggests that the observed urban greening could be associated not only with special tending of the within-city green areas but also
\end{abstract}

with the urban heat islands and succession of more productive shrub and tree species growing on warmer sandy soils.

\section{Introduction}

Significant shifts in the vegetation land cover and biological productivity manifest rapid climate change in the northern high latitudes (Hinzman et al., 2005; Groisman and Gutman, 2013). As in other polar regions, biomes of northern West Siberia (Fig. 1), hereafter referred to as NWS, respond to global warming with complex patterns of multidirectional changes (Bunn and Goetz, 2006; Lloyd and Bunn, 2007; MacDonald et al., 2008; Walker et al., 2009; Bhatt et al., 2013). Although the patterns are geographically fragmented (Elsakov and Teljatnikov, 2013; Barichivich et al., 2014; Guay et al., 2014), the northern biomes (tundra and foresttundra) demonstrate widespread increase of the vegetation productivity ("greening"). Its attribution to tall shrub and graminoids in tundra ecosystems (Frost and Epstein, 2014) and enhanced tree growth in forest-tundra ecosystems (Urban et al., 2014) suggested that we observe transitions to alternative, potentially more productive ecosystems rather than anomalously enhanced biological productivity in response to global warming (Kumpula et al., 2012; Macias-Fauria et al., 2012). These environmental shifts have been unfolding for at least the last 3 decades (Keeling et al., 1996; Myneni et al., 1997) albeit at a slower pace since 2003 (Bhatt et al., 2013).

Simultaneously, the southern biomes (northern and middle taiga forest to the south of about $65^{\circ} \mathrm{N}$ ) demonstrate de- 


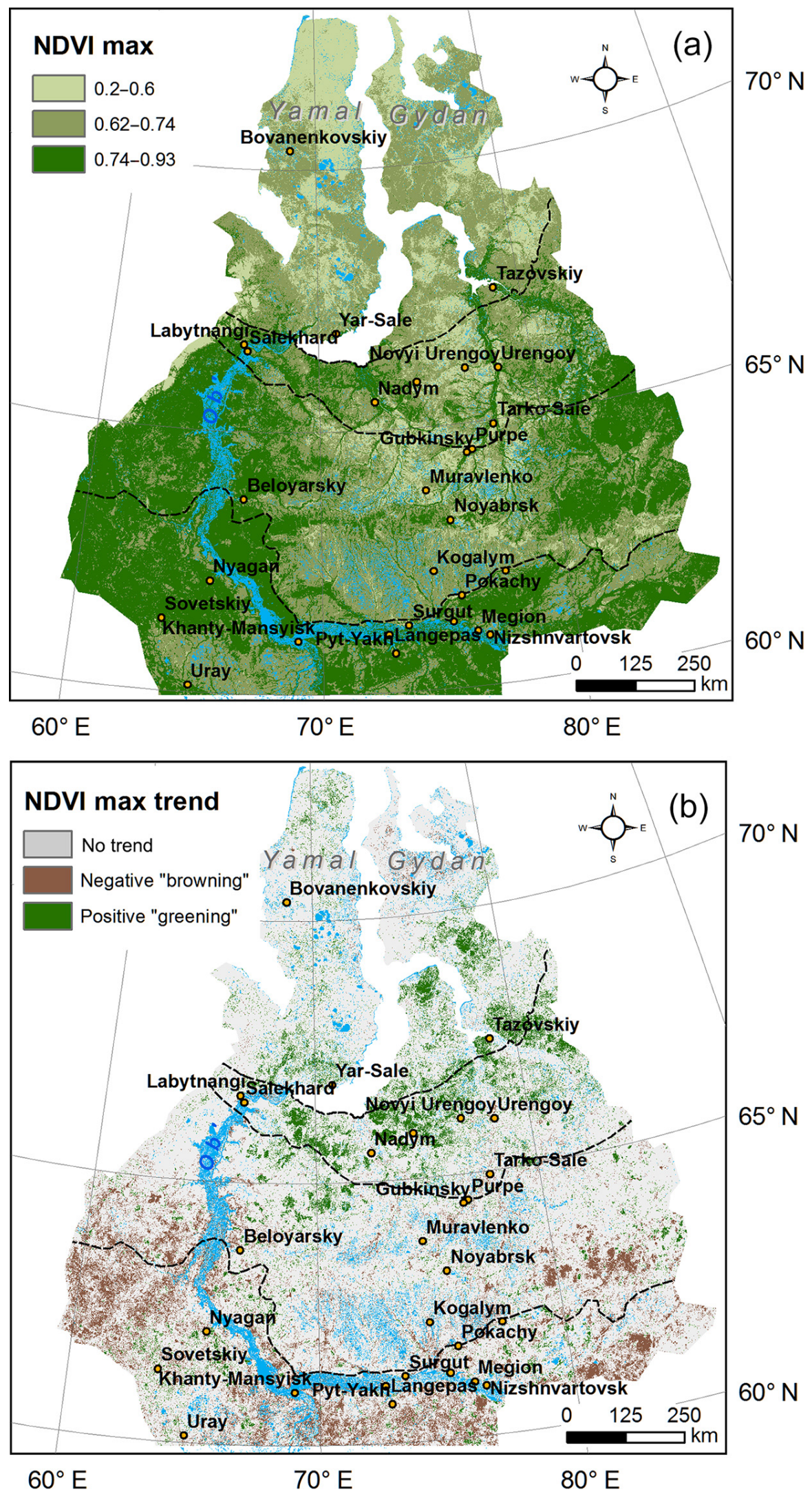

Figure 1. The 15-year mean absolute NDVImax (a) and the statistically significant (at $\alpha<0.05$ ) NDVImax trends for 2000-2014 (b). 
crease of productivity ("browning"). This browning has been robustly associated with decreasing mass of the green leaves, which has been linked to Siberian forest acclimation without the transition to an alternative ecosystem (Lapenis et al., 2005; Lloyd and Bunn, 2007). Although the grown trees are stressed by increasing temperatures, other types of vegetation cover (grass- and shrub-lands, mires) and disturbed patches with young tree seedlings exhibit greening within the same bioclimatic zone.

The persistent greening trends of the disturbed vegetation cover are the focus of this study. Over the last 30-50 years, exploration of oil and gas reserves promoted rapid industrialization and urban development of NWS. It makes this part of the circumpolar region particularly interesting for studies of the emerging alternative ecosystems. The development has left significant footprints on the vegetation cover. These footprints were found not only at the development sites but also across large distances (Walker et al., 2009; Kumpula et al., 2012). More specifically, Kumpula et al. (2011) reported extensive transformation from shrub- to more productive (greener) grass- and sedge-dominated tundra in NWS that reclaim artificial terrain disturbances at Bovanenkovskiy gas field, Yamal peninsula $\left(70^{\circ} \mathrm{N}\right)$. Similar environmental shifts towards more productive plant successions on disturbed patches were found in studies of post-mined sand and sandy loam quarries around Noyabrsk at $63^{\circ} \mathrm{N}$ (Koronatova and Milyaeva, 2011). This transformation across open woodlands and forest-tundra was found to be more ambiguous. A $26 \%$ (from 2316 to $1715 \mathrm{~g} \mathrm{~m}^{-2}$ ) decrease of the total aboveground biomass has been attributed to enhanced bog formation on the background of widespread greening of better drained sandy patches (Moskalenko, 2013). A detailed study by Sorokina (2003) revealed the increased soil temperature by 1 to $4 \mathrm{~K}$ on the disturbed patches within forest, mire and tundra ecosystems. The reclaiming vegetation cover is characterized by increasing share of shrubs (from 18.5 to $27.8 \%$ in the forest ecosystems) and grasses (from less than 0.1 to $8.8 \%$ ) in its above-ground biomass.

Although disturbed patches occupy a relatively small fraction in NWS, their contribution to the observed vegetation productivity changes can be disproportionally significant. For example, for the Yamal peninsula, Elsakov and Teljatnikov (2013) concluded that its widely referred greening (Macias-Fauria et al., 2012) could be traced to statistically significant changes over just $4.8 \%$ of the total area. Moreover, this greening was linked to shrub growth on the patches with disturbed permafrost or within the patches of already established shrubs (Walker et al., 2009). Barichivich et al. (2014) noted that browning in southern forest biomes could also be partially associated with disturbances.

The reviewed literature widely agrees that the observed transformation of vegetation cover represents an alternative ecosystem state (Kumpula et al., 2012; Macias-Fauria et al., 2012) and a new geoecological regime (Raynolds et al., 2014) acclimated to higher temperatures that are likely to persist. This point of view received strong support from the plot-scale International Arctic Tundra Experiment, which simulated warmer climate conditions in high latitudes (Walker et al., 2006; Elmendorf et al., 2012). The question remains whether the plot-scale experiments and field studies at a few carefully selected locations, e.g., Vaskiny Dachi in the central Yamal peninsula (Leibman et al., 2015), could be extrapolated for assessment of the larger scale transition to alternative ecosystems. To approach this question, we use an opportunity provided by the above-mentioned intensive urbanization in NWS. The urbanization created a large number of relatively large-scale (tens of kilometers across) artificial disturbances across all major regional biomes. This study looks at systematic differences in the apparent vegetation productivity trends between the undisturbed background and the areas disturbed by urbanization and industrial development.

As in several previously published studies, this study utilizes a normalized difference vegetation index (NDVI) derived from satellite data products from the Moderate Resolution Imaging Spectroradiometer (MODIS) onboard of the Earth Observing System-Terra platform satellite. Studies by Frey and Smith (2007), Epstein et al. (2012), Macias-Fauria et al. (2012) and others demonstrated that MODIS NDVI could be successfully used in vegetation productivity assessment for Siberian biomes. This study details the previously reported NDVI maps of the region and expands them over the last 15 years (2000-2014) period. The vegetation productivity of emerging alternative ecosystems is calculated at and around of 28 urbanized areas, hereafter referred to as cities. These 28 cities are located in four northern biomes ranging from tundra (Bovanenkovo) to middle taiga forest (Uray).

This paper has the following structure: Data and methods of the study are described in Sect. 2. Section 3 presents the analysis and results for both the background changes in NDVI and NDVI in and around the selected cities. Section 4 discusses the results in the context on previous research and emphasize the role of the cities. Section 5 outlines conclusions.

\section{Data and methods}

This study is based on analysis of the maximum summer NDVI, which we denote as NDVImax. NDVImax was obtained from MODIS NDVI 16-day composites with the $250 \mathrm{~m}$ spatial resolution (MOD13Q1). The data were downloaded from the NASA's Earth Observing System Data and Information System (EOSDIS) for 15 summers (June-JulyAugust, JJA) covering the period 2000-2014. 


\subsection{The maximum normalized difference vegetation index, NDVImax}

NDVI is defined as a normalized ratio of reflectance factors in the near infrared (NIR) and red spectral radiation bands

$\mathrm{NDVI}=\frac{\rho_{\mathrm{NIR}}-\rho_{\mathrm{RED}}}{\rho_{\mathrm{NIR}}+\rho_{\mathrm{RED}}}$,

where $\rho_{\mathrm{NIR}}$ and $\rho_{\mathrm{RED}}$ are the surface bidirectional reflectance factors for their respective MODIS bands on the TERRA platform satellite. NDVI exploits the contrast between the red and NIR reflectance of vegetation, as chlorophyll is a strong absorber of the red light, while the internal structure of leaves reflects highly in the NIR. The greater the difference between the reflectance in the red and NIR portions of the spectrum, the more chlorophyll is found in vegetation canopy. Vegetation generally yields positive NDVI values, which approach +1 with increasing plant chlorophyll content or green aboveground biomass. NDVI with the values below 0.2 generally corresponds to non-vegetated surfaces, whereas green vegetation canopies have NDVI greater than 0.3 .

NDVI in remote-sensing studies is a popular proxy for gross photosynthesis, and therefore, for vegetation productivity (Goetz et al., 2005). A strength of NDVI is its normalization, which makes it relatively insensitive to radiometric attenuation (e.g., by cloud shadows) present in multiple bands. The main weakness of NDVI is its inherent nonlinearity that leads to asymptotic saturation of NDVI over higher biomass conditions. This saturation, also known as the NDVI degradation, is particularly strong in the areas with higher canopy background brightness corresponding to the most productive biomes. By contrast, the biomass accumulation in the less productive biomes could be approximated with a linear regression model. NDVI typically does not degrade in tundra (Raynolds et al., 2012), but the degradation should be empirically taken into account in NDVI interpretations for more southern biomes (D'Arrigo et al., 2000; Zhang et al., 2004).

A remarkably strong correlation $\left(R^{2}=0.94, p<0.001\right)$ was found between total above-ground phytomass sampled at the peak of summer and the maximum annual NDVI (NDVImax) in studies of the North America and Eurasia transects (Raynolds et al., 2012). This strong relationship encouraged us to use NDVImax in this study. NDVImax is a more conservative characteristic of the vegetation cover that is linked to the total biomass at the late phenological phases. Moreover, NDVImax eliminates seasonal variations and the relative shifts between phenological phases in different climatic zones. Hence, NDVImax is particularly convenient for and frequently used in the environmental studies dealing with long-term and large-scale changes, including effects of the climate change.

NDVImax was obtained from MOD13Q1 data product. This product is distributed in adjacent non-overlapping tiles with the side of approximately $10^{\circ}$ (at the equator) and the Si- nusoidal (SIN) tile grid projection (Solano et al., 2010). Five tiles to cover the entire area of interest (total 20 tiles per each summer) were downloaded and imported into the ArcGIS geographic information system. Images were combined and reprojected from the original SIN to the Universal Transverse Mercator projection (UTM Zone 42N, WGS84 ellipsoid). The data were quality-filtered by the MODIS reliability data provided together with the MOD13Q1 product. Only data of the highest quality, which excluded snow/ice- and cloud covered pixels, were retained. The NDVI $>0.3$ criterion was used here to exclude water, bare soil and other non-vegetated pixels from the analysis. The data gaps in the raster mosaic pixels were then filled with information using the nearest neighbor statistical interpolation from the surrounding pixels with data. Finally, NDVImax maps for each summer were obtained through identification of the maximum NDVI value from each 16-day composite for each pixel. The analysis operates with these NDVImax maps of the $250 \mathrm{~m}$ resolution covering the 15 year period 2000-2014.

\subsection{NDVImax in and around selected cities}

The NWS territory provides a unique opportunity for statistical study, which compares the effect of recent urbanization along with the effect on the climate change on the vegetation land cover in and around cities across several northern biomes. Twenty-eight (28) cities, some of them with more than 100000 inhabitants (see Table 1), were selected. NDVImax was studied within $40 \mathrm{~km}$ buffer zones around each city. Each buffer zone was broken into 8 rings of $5 \mathrm{~km}$ width centered at the city core zone. This approach is similar to one used by Zhang et al. (2004).

Let us introduce $<\operatorname{NDVImax}(t, i, n)>$ as the NDVImax value in the year $t=1 \ldots 15$ for the ring number $i=0 \ldots 8$ (the ring $i=0$ corresponds to the city core and $i=8-$ to the most distant background ring) in the city $n=1 \ldots .28$ that is averaged over all pixels within the ring. This approach does not differentiate between the vegetation productivity changes and the changes of the vegetation biological composition (succession). In this sense, it will be insensitive to the NDVImax trends due to urban expansion, shifting vegetation disturbances and re-vegetation. As the $<\operatorname{NDVImax}(t, i, n)>$ values strongly vary from city to city and across different biomes, it is convenient to introduce a relative footprint of a city as

$F(t, i, n)=\frac{<\operatorname{NDVImax}(t, i, n)>}{<\operatorname{NDVImax}(i, n)>}$

and the relative linear trends, $R(i, n)$, which are computed by the least-squares fit of $F(t, i, n)$ to the first-order polynomial for the ring $i$ in the city $n, \overline{\langle\operatorname{NDVImax}(i, n)\rangle}$ is time-averaged $<\operatorname{NDVImax}(t, i, n)>$. Because the study operates with rather short 15 -year time series, the years with the maximum and the minimum NDVImax can strongly impact the trends. These 2 years (2002 and 2014 for the majority 
Table 1. List of 28 urban and industrial areas (cities) considered in this study. The city population (pop. in thousands inhabitants) is estimated according to the Russian national census for 2010. The mean background NDVImax (nature) is given for the most distant $40 \mathrm{~km}$ ring. The relative trends are given for the time series without the years with the minimum and maximum NDVImax. Statistically significant trends at $95 \%$ level are underlined. The biomes are abbreviated as tundra (T); forest-tundra (FT); norther taiga forest (NTF); and middle taiga forest (MTF).

\begin{tabular}{|c|c|c|c|c|c|c|c|c|}
\hline$N$ & $\begin{array}{l}\text { City } \\
\text { name }\end{array}$ & Coord. & $\begin{array}{r}\text { Pop. } \\
(\times 1000)\end{array}$ & Biome & $\begin{array}{r}\text { Mean NDVImax } \\
\text { (nature) }\end{array}$ & $\begin{array}{l}\text { NDVImax trend (nature) } \\
{\left[\% \mathrm{dec}^{-1}\right]}\end{array}$ & $\begin{array}{r}\text { Mean NDVImax } \\
\text { (city core) }\end{array}$ & $\begin{array}{r}\text { NDVImax trend } \\
\text { (city core) }\left[\% \mathrm{dec}^{-1}\right]\end{array}$ \\
\hline 1 & Beloyarsky & $\begin{array}{l}63^{\circ} 42^{\prime} \mathrm{N} \\
66^{\circ} 40^{\prime} \mathrm{E}\end{array}$ & $\downarrow 49$ & NTF & 0.78 & $-0.6 \%$ & 0.65 & $+3.0 \%$ \\
\hline 2 & Bovanenkovskiy & $\begin{array}{l}70^{\circ} 21^{\prime} \mathrm{N} \\
68^{\circ} 32^{\prime} \mathrm{E}\end{array}$ & $2-6$ & $\mathrm{~T}$ & 0.65 & $+1.4 \%$ & 0.57 & $-10 \%$ \\
\hline 3 & Gubkinsky & $\begin{array}{l}64^{\circ} 26^{\prime} \mathrm{N} \\
76^{\circ} 27^{\prime} \mathrm{E}\end{array}$ & $\downarrow 26$ & FT & 0.65 & $-1.1 \%$ & 0.53 & $+1.1 \%$ \\
\hline 4 & Khanty-Mansyisk & $\begin{array}{l}61^{\circ} 48^{\prime} \mathrm{N} \\
69^{\circ} 10^{\prime} \mathrm{E}\end{array}$ & $\uparrow 93$ & MTF & 0.78 & $-2.6 \%$ & 0.62 & $-3.0 \%$ \\
\hline 5 & Kogalym & $\begin{array}{l}62^{\circ} 14^{\prime} \mathrm{N} \\
74^{\circ} 32^{\prime} \mathrm{E}\end{array}$ & $\uparrow 61$ & MTF & 0.69 & $-1.3 \%$ & 0.65 & $-2.0 \%$ \\
\hline 6 & Labytnangi & $\begin{array}{l}66^{\circ} 39^{\prime} \mathrm{N} \\
66^{\circ} 25^{\prime} \mathrm{E}\end{array}$ & $\uparrow 26$ & FT & 0.75 & $-2.0 \%$ & 0.60 & $+\underline{+6.0 \%}$ \\
\hline 7 & Langepas & $\begin{array}{l}61^{\circ} 15^{\prime} \mathrm{N} \\
75^{\circ} 10^{\prime} \mathrm{E}\end{array}$ & $\uparrow 43$ & MTF & 0.77 & $-1.9 \%$ & 0.72 & $+1.4 \%$ \\
\hline 8 & Megion & $\begin{array}{l}61^{\circ} 22^{\prime} \mathrm{N} \\
76^{\circ} 06^{\prime} \mathrm{E}\end{array}$ & $\downarrow 49$ & MTF & 0.77 & $+0.8 \%$ & 0.52 & $\pm 6.9 \%$ \\
\hline 9 & Muravlenko & $\begin{array}{l}63^{\circ} 47^{\prime} \mathrm{N} \\
74^{\circ} 31^{\prime} \mathrm{E}\end{array}$ & $\downarrow 33$ & NTF & 0.65 & $-1.0 \%$ & 0.47 & $-3.6 \%$ \\
\hline 10 & Nadym & $\begin{array}{l}65^{\circ} 32^{\prime} \mathrm{N} \\
72^{\circ} 31^{\prime} \mathrm{E}\end{array}$ & $\downarrow 46$ & NTF & 0.71 & $+1.2 \%$ & 0.55 & $-1.8 \%$ \\
\hline 11 & Nefteugansk & $\begin{array}{l}61^{\circ} 55^{\prime} \mathrm{N} \\
72^{\circ} 36^{\prime} \mathrm{E}\end{array}$ & $\downarrow 126$ & MTF & 0.76 & $-2.1 \%$ & 0.56 & $-3.0 \%$ \\
\hline 12 & Nizshnvartovsk & $\begin{array}{l}60^{\circ} 56^{\prime} \mathrm{N} \\
76^{\circ} 33^{\prime} \mathrm{E}\end{array}$ & $\downarrow 266$ & MTF & 0.78 & $-1.8 \%$ & 0.60 & $-4.7 \%$ \\
\hline 13 & Novyi Urengoy & $\begin{array}{l}66^{\circ} 05^{\prime} \mathrm{N} \\
76^{\circ} 04^{\prime} \mathrm{E}\end{array}$ & $\downarrow 116$ & NTF & 0.63 & $\underline{+4.0 \%}$ & 0.54 & $+3.8 \%$ \\
\hline 14 & Noyabrsk & $\begin{array}{l}63^{\circ} 11^{\prime} \mathrm{N} \\
75^{\circ} 27^{\prime} \mathrm{E}\end{array}$ & $\downarrow 107$ & MTF & 0.69 & No change & 0.60 & $+0.6 \%$ \\
\hline 15 & Nyagan & $\begin{array}{l}62^{\circ} 08^{\prime} \mathrm{N} \\
65^{\circ} 24^{\prime} \mathrm{E}\end{array}$ & $\uparrow 56$ & MTF & 0.79 & $-0.7 \%$ & 0.59 & $\pm 4.6 \%$ \\
\hline 16 & Pangody & $\begin{array}{l}65^{\circ} 51^{\prime} \mathrm{N} \\
74^{\circ} 31^{\prime} \mathrm{E}\end{array}$ & $\uparrow 11$ & FT & 0.68 & $+3.6 \%$ & 0.49 & $-2.1 \%$ \\
\hline 17 & Pokachy & $\begin{array}{l}61^{\circ} 44^{\prime} \mathrm{N} \\
75^{\circ} 35^{\prime} \mathrm{E}\end{array}$ & $\uparrow 17$ & MTF & 0.74 & $-1.5 \%$ & 0.53 & $+1.6 \%$ \\
\hline 18 & Purpe & $\begin{array}{l}64^{\circ} 29^{\prime} \mathrm{N} \\
76^{\circ} 42^{\prime} \mathrm{E}\end{array}$ & $\downarrow 10$ & FT & 0.67 & $-0.4 \%$ & 0.49 & $\underline{-4.3 \%}$ \\
\hline 19 & Pyt-Yakh & $\begin{array}{l}60^{\circ} 44^{\prime} \mathrm{N} \\
72^{\circ} 49^{\prime} \mathrm{E}\end{array}$ & $\uparrow 41$ & MTF & 0.81 & $-2.0 \%$ & 0.67 & $+1.1 \%$ \\
\hline 20 & Raduzhnyi & $\begin{array}{l}62^{\circ} 06^{\prime} \mathrm{N} \\
77^{\circ} 28^{\prime} \mathrm{E}\end{array}$ & $\downarrow 43$ & MTF & 0.72 & $-1.5 \%$ & 0.65 & $-0.3 \%$ \\
\hline 21 & Salekhard & $\begin{array}{l}66^{\circ} 31^{\prime} \mathrm{N} \\
66^{\circ} 36^{\prime} \mathrm{E}\end{array}$ & $\uparrow 48$ & FT & 0.75 & $-0.9 \%$ & 0.54 & $+5.5 \%$ \\
\hline 22 & Sovetskiy & $\begin{array}{l}61^{\circ} 21^{\prime} \mathrm{N} \\
63^{\circ} 34^{\prime} \mathrm{E}\end{array}$ & $\uparrow 28$ & MTF & 0.79 & $-0.6 \%$ & 0.57 & $0.9 \%$ \\
\hline 23 & Surgut & $\begin{array}{l}61^{\circ} 15^{\prime} \mathrm{N} \\
73^{\circ} 24^{\prime} \mathrm{E}\end{array}$ & $\uparrow 332$ & MTF & 0.75 & $-2.4 \%$ & 0.53 & $-0.2 \%$ \\
\hline 24 & Tarko-Sale & $\begin{array}{l}64^{\circ} 55^{\prime} \mathrm{N} \\
77^{\circ} 47^{\prime} \mathrm{E}\end{array}$ & $\uparrow 21$ & FT & 0.69 & $-0.6 \%$ & 0.51 & $\underline{-5.9 \%}$ \\
\hline 25 & Tazovskiy & $\begin{array}{l}67^{\circ} 28^{\prime} \mathrm{N} \\
78^{\circ} 42^{\prime} \mathrm{E}\end{array}$ & $\downarrow 7$ & NTF & 0.73 & $+1.5 \%$ & 0.63 & $\pm 7.6 \%$ \\
\hline 26 & Uray & $\begin{array}{l}60^{\circ} 07^{\prime} \mathrm{N} \\
64^{\circ} 46^{\prime} \mathrm{E}\end{array}$ & $\uparrow 40$ & MTF & 0.76 & $-0.2 \%$ & 0.67 & $+0.5 \%$ \\
\hline 27 & Urengoy & $\begin{array}{l}65^{\circ} 57^{\prime} \mathrm{N} \\
78^{\circ} 21^{\prime} \mathrm{E}\end{array}$ & $\downarrow 11$ & FT & 0.68 & $-1.0 \%$ & 0.55 & $-2.1 \%$ \\
\hline 28 & Yar-Sale & $\begin{array}{l}66^{\circ} 52^{\prime} \mathrm{N} \\
70^{\circ} 49^{\prime} \mathrm{E}\end{array}$ & $\downarrow 7$ & $\mathrm{~T}$ & 0.66 & $+3.9 \%$ & 0.52 & $-2.8 \%$ \\
\hline
\end{tabular}




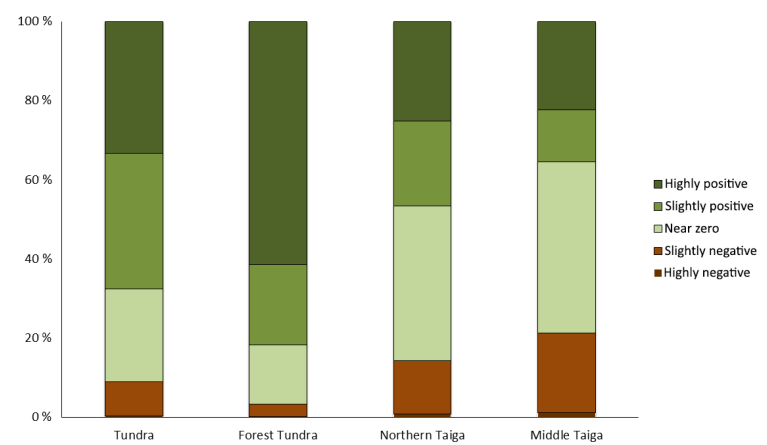

Figure 2. Total fractional areas of NDVImax changes for classes as defined in Table 2.

of cities) can be considered as outliers as their NDVImax were beyond 3 standard deviations of the respective time series. We demonstrate this for four cities (Bovanenkovsky, Nadym, Noyabrsk and Surgut) in Fig. 3. Therefore, the years with minimum and maximum NDVImax were excluded from the trend fitting. We will also consider the differences in the relative footprints, $\Delta F(i, j, n)=\overline{F(t, i, n)}-\overline{F(t, j, n)}$, and relative differences in the trends, $\Delta R(i, j)=R(i)-R(j)$, between the rings $i$ and $j$ for the city $n$. The urbanization footprint could be characterized through the divergent trends: $\Delta R(0,8)$ - between the city core and the corresponding natural land cover; $\Delta R(0,5)$ - between the core and the first ring around it; and $\Delta R(5,8)$ - between supposedly the most affected $5 \mathrm{~km}$ ring and the background $40 \mathrm{~km}$ ring.

\section{Results}

\subsection{Regional NDVImax patterns and trends}

Our study expands, updates and details the results of the NDVImax analysis for 1981-1999 by Zhou et al. (2001), 1982-2003 by Bunn and Goetz (2006), 1982-2008 by Beck and Goetz (2011), 1982-2011 by Barichivich et al. (2014) and 2000-2009 by Elsakov and Teljatnikov (2013). Two novel aspects should be mentioned in this context: (1) whereas the previous studies analyzed coarse-resolution data, which is likely to exaggerate the extent and magnitude of the NDVImax trends (Zhao et al., 2009; Elsakov and Teljatnikov, 2013), we use the fine-resolution $(250 \mathrm{~m})$ data; and (2) fine-resolution data give an opportunity to trace the changes to specific biomes within the same bioclimatic zone and to reveal effects of urban disturbances.

The updated mean NDVImax and NDVImax trend maps (2000-2014) are shown in Fig. 1a and b, respectively. NDVImax in NWS generally decreases from the southwest to the northeast of the territory. The largest NDVImax values (the most productive vegetation) are found along the $\mathrm{Ob}$ river and between the $\mathrm{Ob}$ river and Ural mountains, whereas the central, swamped part of NWS has much lower NDVImax.
We observe that NDVImax is significantly higher on river terraces with better-drained, sandy soils, which are warmer in summertime and have deeper seasonal active layer. The new maps confirm continuing widespread greening in tundra and forest-tundra biomes. However, this greening is highly fragmented and to a large degree could be associated with sandy soils as well as with smaller greening patches associated with permafrost destruction, landslides, thermokarst and other local disturbances. Figure $1 \mathrm{~b}$ shows the statistically significant trends. It clearly demonstrates that the previously reported widespread greening trends are statistically insignificant. The most significant areas of greening are found in Taz and southern Gydan peninsulas. This finding is in good agreement with previously reported plot scale studies using LANDSAT images. Table 2 and Fig. 2 aggregate the greening and browning trends in the NWS biomes. They show that the forest biomes exhibit more widespread and larger magnitude browning. The maximum area fraction of browning $(21.3 \%)$ was found in middle taiga and the minimum area fraction $(8.9 \%)$ - in tundra biomes. Contrary, the area fraction of greening is the largest $(81.7 \%)$ in forest-tundra and the smallest $(35.5 \%)$ in middle taiga biomes.

Comparison with Lloyd and Bunn (2007), Bhatt et al. (2013) and Elsakov and Teljatnikov (2013) studies further reveals that the area of more productive vegetation cover continue to grow as well as the production in shruband graminoid-dominated ecosystems. Despite colder recent winters (Cohen et al., 2012) and somewhat damped summer warming (Tang and Leng, 2012), the greening now dominates the changes in all four biomes. We observe the strongest greening near the southern tundra boundary. This pattern is consistent with previously noted shrubification and treeline advance in this area (Devi et al., 2008; MacDonald et al., 2008).

\subsection{NDVImax patterns and trends in and around 28 cities}

Disturbances of the vegetation cover around 28 cities in NWS considerably modify the observed complex pattern of the background NDVImax trends. In this analysis, we distinguish the city core, $i=0$, with strongly disturbed vegetation cover and therefore low NDVImax and the rings $i=1 \ldots 8$ where the area of disturbances progressively decreases with the distance from the city core. Figure 3 shows the analysis of NDVImax changes for four typical cities located in four different biomes. The observed convergence of the statistical properties of NDVImax in the rings $i=4 \ldots 7$ to those in the ring 8 supports the intuitive assumption that the area fraction of urban disturbances is gradually reduced with the distance from the city. Indeed, the correlation coefficients between time series of $F(t, 0, n)$ and $F(t, i, n), i=1 \ldots 8$, are decreasing with larger $i$ (see the upper panels in Fig. 3).

Now, we consider differences between the background NDVImax trends and the trends over the disturbed vegeta- 
(a)
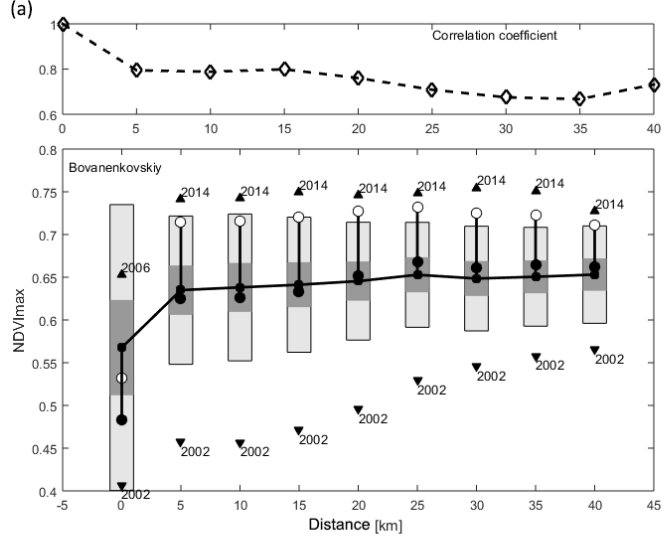

(c)
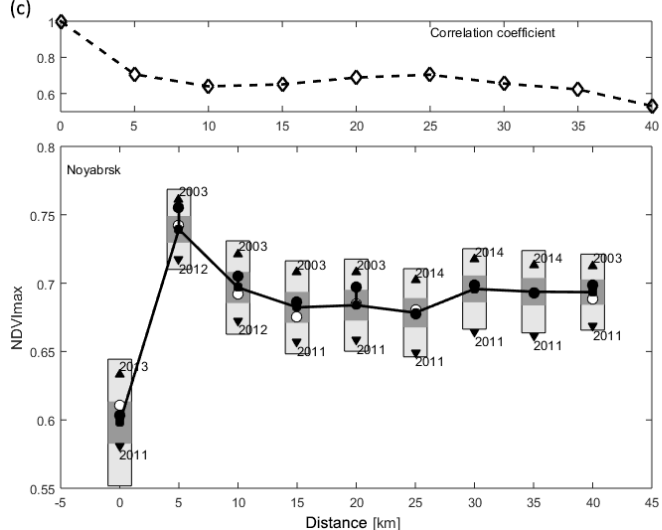

(b)
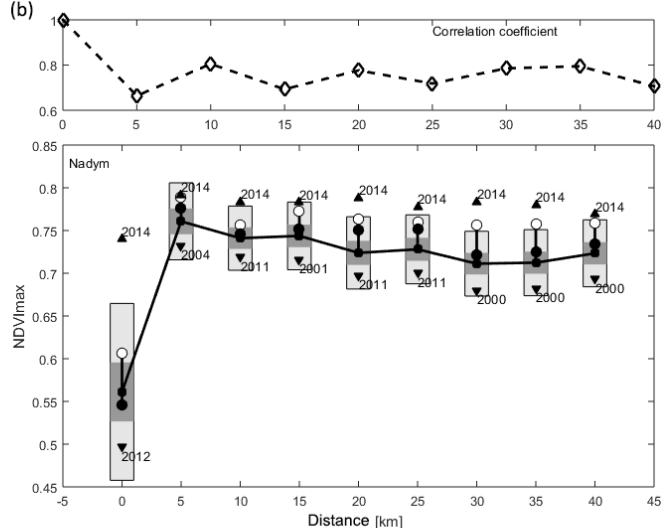

(d)
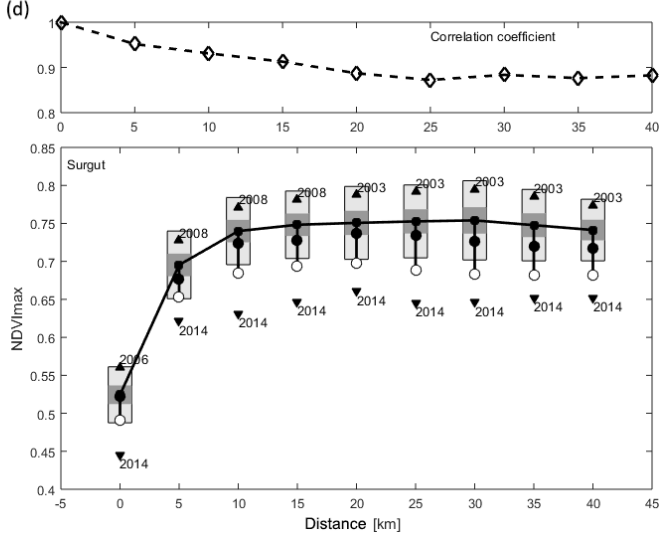

Figure 3. The statistical structure of NDVImax, correlations and trends at the city-core and the eight rings in the buffer zones of Bovanenkovskiy (tundra), Nadym (tundra-forest), Noyabrsk (northern taiga) and Surgut (middle taiga). The distance is given in kilometers from the central pixel of each city core. The upper panels for each city show the decay of correlations (extreme years were excluded from the calculation) between the NDVImax variations at the city core and in the corresponding distance. The lower panels show bold line with squares - the mean NDVImax; dark gray rectangle - 1 standard deviation of NDVImax for each ring; light gray rectangles - 3 standard deviations; triangles - the years with the maximum (upward-looking triangle) and the minimum (downward-looking triangle) of NDVImax; vertical black line with white circle - the magnitude of the NDVImax change obtained as the trend multiplied by 15 years; black circle - the same as the white circle but for the trends obtained when the maximum and the minimum NDVImax were excluded.

Table 2. Fractional areas of the NDVImax changes for 2000-2014 in four NWS biomes

\begin{tabular}{llrrrr}
\hline & NDVImax change & Tundra & Forest Tundra & Northern Taiga & Middle Taiga \\
\hline Highly negative & $\leq-0.006$ & $0.28 \%$ & $0.18 \%$ & $0.73 \%$ & $1.05 \%$ \\
Slightly negative & -0.006 to -0.003 & $8.58 \%$ & $3.12 \%$ & $13.48 \%$ & $20.25 \%$ \\
Near zero & -0.003 to 0.003 & $23.56 \%$ & $15.01 \%$ & $39.19 \%$ & $43.18 \%$ \\
Slightly positive & 0.003 to 0.006 & $34.25 \%$ & $20.33 \%$ & $21.38 \%$ & $13.16 \%$ \\
Highly positive & $0.006<$ & $33.33 \%$ & $61.36 \%$ & $25.22 \%$ & $22.36 \%$ \\
\hline
\end{tabular}

tion cover in and around the cities. Figure $4 \mathrm{a}$ and $\mathrm{c}$ show that all cities have strongly reduced NDVImax values. Some cities have NDVImax reduced by more than $30 \%$ as compared to the background. As it has been already suggested by Fig. 3 (for Nadym and, particularly, for Noyabrsk), the closest $5 \mathrm{~km}$ ring $(i=1)$ often exhibits higher NDVImax than the more distant background. This unusual feature could be traced down to the preferential location of the cities on gen- erally greener river terraces. So that the greener patches contribute more heavily to the mean NDVImax of the inner rings.

Apart from lower NDVImax in the city cores, Fig. 4d reveals two opposite dependences between the vegetation disturbance and the vegetation productivity. The cities with larger relative NDVImax reduction (the large negative $\Delta F$ ) demonstrate the accelerated NDVImax recovery (the large positive $\Delta R$ ). This rapid recovery at the initial stages of the 

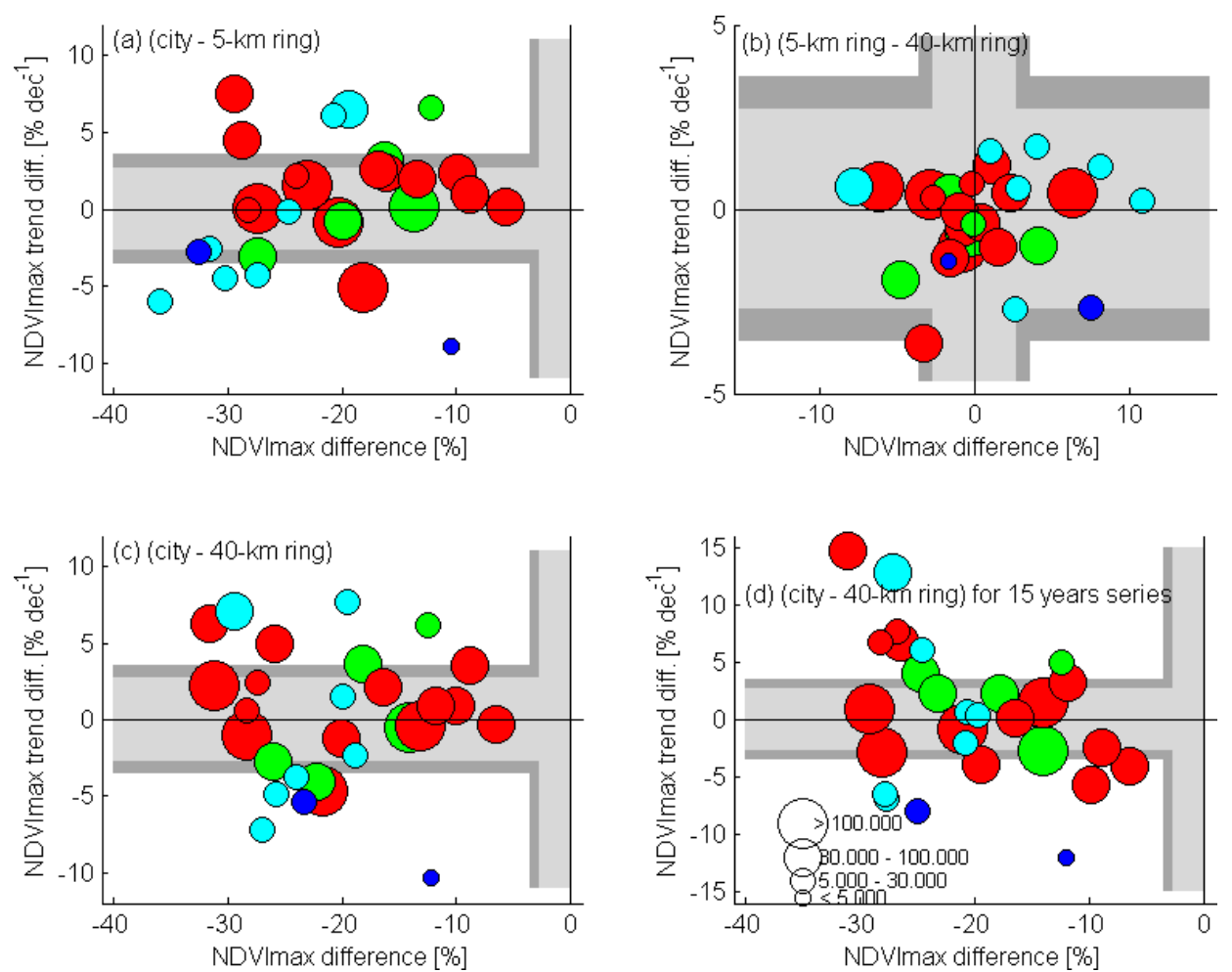

Figure 4. The relative changes $\Delta F(i, j)$ ( $x$ axis) and $\Delta R(i, j)$ (y axis) given in percentage for (a) the city core $(i=0)$ and the closest $5 \mathrm{~km}$ ring $(j=1)$; (b) the closest $(i=1)$ and the most distant background $(j=8)$ rings; and (c) the city core $(i=0)$ and the ring $(j=8)$. The numbers were obtained for the time series without the years of the maximum and minimum NDVImax. Panel (d) shows the same as (c) but for the full 15-year time series. The circle color indicates blue - tundra; cyan - forest-tundra; green - northern taiga; red - middle taiga. The circle size indicates the city population in 2005 as shown on panel (d). The gray shading shows the statistical confidence envelopes (99\% dark gray shading; $95 \%$ - light gray shading).

vegetation succession has been repeatedly noted in several plot-scale studies (Sorokina, 2003; Archegova, 2007; Koronatova and Milyaeva, 2011) and high-resolution satellite image analyses (Kornienko and Yakubson, 2011; Kumpula et al., 2011). Unfortunately, the majority of these studies have been published in Russian only. Intercomparison with Fig. 4c, where this dependence is less pronounced, suggests that the vegetation cover in cities is more resistant to the stress in the extreme warm and cold years. Moreover, the protecting effect of the city is stronger for the northern cities responding with strong greening due to extremely warm summer temperatures.

It is interesting to observe that the effect of cities does not exhibit clear regular dependence on the city population or specific location. The only visible effect in Fig. 4a could be attributed to the age of the city - the younger northern cities continue to destroy vegetation cover as they expand, whereas the vegetation cover in the established southern cities recovers. Figure $4 \mathrm{~b}$ shows that the disturbances have the largest positive effect on both the mean NDVImax and its trends in the forest-tundra biome. Here, 6 out of 7 cities induce the accelerated greening in the $5-\mathrm{km}$ ring.

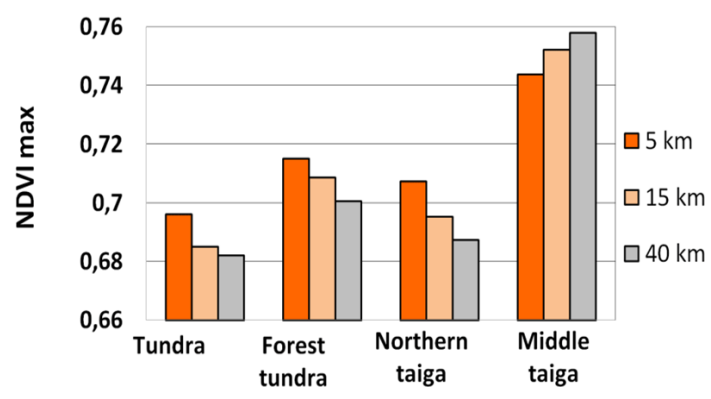

Figure 5. Aggregated NDVImax for $5 \mathrm{~km}$ (closest to the city core), 15 and $40 \mathrm{~km}$ (the most distant background) rings around the cities in the corresponding four biomes.

The biome-averaged impact of the urban disturbances on NDVImax is given in Fig. 5. The analysis shows that the city footprint is visible at large distances. Even at the $15 \mathrm{~km}$ distance from the city core, NDVImax is systematically higher in the northern biomes and lower in the middle taiga biome. Moreover, NDVImax is also systematically the highest in the closest $5-\mathrm{km}$ ring where the area of disturbances is the largest. Figure 6 illustrates the vegetation changes leading to 

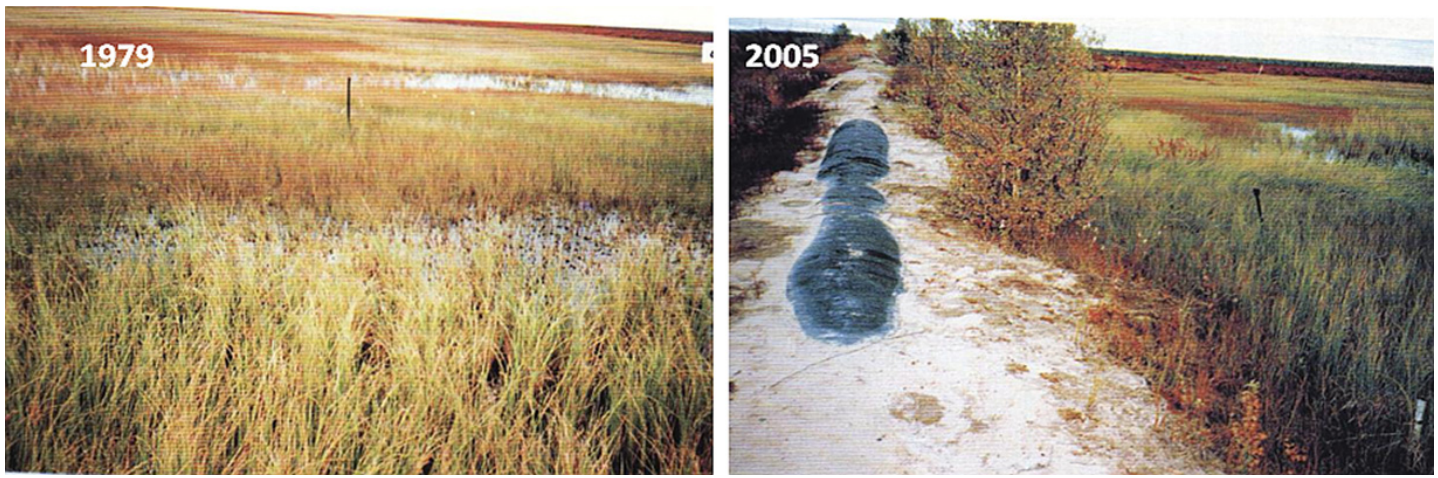

Figure 6. Illustration of the alternative ecosystem development on anthropogenically disturbed patches. The vegetation cover changes along the gas pipeline Nadym-Punga.

higher biological productivity of the disturbed land patches in the northern biomes. The newly established tree seedlings and shrubs, which are more productive relative to the background in the northern biomes, are less productive relative to the background of the mature trees in the middle taiga biome.

\section{Discussion}

The results of the presented high-resolution NDVImax analysis in 2000-2014 show continuing changes in the vegetation land cover and vegetation productivity in NWS. In general, the northern biomes (tundra and forest-tundra north of about $65^{\circ} \mathrm{N}$ ) and to some degree open swamped areas within the forest biomes demonstrate persistent greening, whereas the forested areas showed similarly persistent browning. More detailed analysis has however revealed that the statistically significant changes are highly fragmented. Such changes occupy only a minor fraction of NWS and often could be collocated with natural or anthropogenic disturbances of the vegetation cover. This observation lead Macias-Fauria et al. (2012) and Kumpula et al. (2012) to hypothesize that those disturbances help to establish alternative, more productive ecosystems of graminoids, shrubs and tree seedlings. In this discussion, we consider the major climatological and physical factors that may support the alternative vegetation cover.

The cold continental climates of the NWS (the KöppenGeiger climate types Dfc and ET) with relatively high amount of annual precipitation determine a short growing season and strong dependence of the maximum vegetation productivity on summer temperatures (Barichivich et al., 2014). This dependence is not of universal character across biomes. The higher spring-summer temperatures (Bhatt et al., 2013; Ippolitov et al., 2014) and larger amount of accumulated snow (Bulygina et al., 2011) favor the tall deciduous shrub (Betula nana and different Salix species) in tundra and forest-tundra (e.g Sturm et al., 2001; Elmendorf et al., 2012). Similarly, grasses (graminoids) respond on higher spring temperatures with higher biomass production. It should be emphasized however that the associations between the NDVImax trends and productivity of the specific ecosystems within the arctic biomes remain rather loose (Frey and Smith, 2007; Kornienko and Yakubson, 2011). Moreover, even synthetic NDVImax time series (Guay et al., 2014) are too short and too variable for statistically robust conclusions over the major part of the area.

The response on the observed climate change is different in the forest biomes. Summertime surface air temperatures increased only weakly in central and southern NWS (Shulgina et al., 2011; Ippolitov et al., 2014) likely being damped by increasing cloud cover (Tang and Leng, 2012; Esau et al., 2012). The temperature trends in the winter months were negative (Cohen et al., 2012; Outten and Esau, 2011; Outten et al., 2013). Thus, there were no consistent warming trends over this territory but rather a few summer heat waves (e.g. in 2002, 2007, 2012) with certain impact on the forest productivity.

As the reviewed literature discloses, the direct impact of the climate factors on the vegetation cannot be established unambiguously. Even conclusions derived from the analysis of common data sets differ on the relative role of the climate change and the natural decadal variability. For example, Melnikov et al. (2004) concluded that the climatic trends are only weakly discernable in the active soil layer data, whereas Streletsky et al. (2012) found a significant increase (up to $0.3 \mathrm{~m}$ ) of the active layer thickness. Moreover, simulations of the forest biomass productivity with a stand-alone dynamic vegetation model by Schumann and Shugart (2009) produced no significant productivity change at Siberian forest sites for the warming below $2 \mathrm{~K}$. At the same time, the observed biome-wide dichotomy of the grass-covered area greening versus the tree-covered area browning was reproduced in the anthropogenic global warming experiments with the Community Atmospheric Model version 3 with the LundPotsdam-Jena dynamic vegetation model (Jeong et al., 2012). 
A more coherent picture has been suggested by studies of vegetation reclaiming the natural or anthropogenic disturbances (Kornienko and Yakubson, 2011; Kumpula et al., 2011). Lloyd et al. (2003) concluded that the establishment and seasonal growth of woody species at the Alaska treeline was likely limited by the availability of disturbed welldrained microsites. They suggested that the vegetation response to regional climatic changes is presently controlled by the availability of such microsites. This study supports the idea of the changes limited to the disturbed microsites availability. We found a very fragmented pattern of changes in the NWS. The larger changes near the cities are consistent with the large impact of re-populated microsites with stronger woody vegetation on the NDVImax trends. In this sense, human activity and urbanization create variety of the disturbed microsites needed for establishing more productive vegetation.

The soil disturbances significantly modify both the surface heat balance and the drainage conditions in the area. Pavlov and Moskalenko (2002) and more recently Yu et al. (2015) showed that the disturbed soils in tundra and northern taiga (near Nadym) are warmer and accumulated more heat (thaw deeper) during the summer seasons. Establishing woody species may revert this process. Thus, although Lloyd et al. (2003) found that woody species are more readily established on disturbed microsites with better drainage and drier warmer soils, Juszak et al. (2016) showed poor soil thermal conductivity below grown dwarf shrub microsites, which results in thinner active soil layer and worse rooting conditions. Frost et al. (2013) studies in our NWS area strongly support the envisaged transformation of the soil conditions. They reported higher soil temperatures during the colonization phase and lower temperatures during the mature phase of Alnus growth. Figure 6 illustrates the shrub establishment on disturbed microsites.

Mosaic of vegetation changes on "microsites" is readily observable in field studies. More general discussion with relevance to the observed changes in the biomass production, however, should account for other physical and biological processes in the active soil layers. Better drainage gives better rooting conditions for forbs and trees as well as increasing organic mass loss in soils, litter decomposition and decreasing moss productivity (Hicks Pries et al., 2013). Yakubson et al. (2012) reported high correlation between the enhanced NDVImax and dryer soils at the disturbed areas around Bovanenkovo. Similar dependences were found over Taz peninsula (Kornienko and Yakubson, 2011). Brunsell et al. (2011) showed that the boundary layer dynamics with enhanced micro-circulations over the microsites might additionally increase the surface temperature heterogeneity, enhancing the sensible heat flux by as much as $50 \mathrm{Wm}^{-2}$ for larger disturbances. Our results for the $5 \mathrm{~km}$ ring seem to support this feedback hypothesis.

Summarizing this discussion on the relative role of the changes in drainage and the surface heat balance, we com- ment that while woody vegetation demonstrates a clear phenotypical response on better drainage conditions, the areaaverage biomass productivity has stronger response on the soil temperature as found by Barichivich et al. (2014).

Cities and industrial installations in NWS are frequently built-up on sand beds. It may partially explain the more positive NDVImax trends found in and around the city cores. Koronatova and Milyaeva (2011) studied plant succession over 1999-2010 in post-mined sandy and loam quarries around Noyabrsk city. The quarries were colonized by pine seedlings already during the first 5 years, skipping the grass community stage, and an open pine community with green moss and lichen species was established by year 20 .

Finally, it is fruitful to comment on the relative roles of climate changes and the anthropogenic disturbances introduced through the new infrastructure development. Yu et al. (2015) compared the vegetation changes around Nadym using high spatial resolution imagery acquired in 1968 and 2006. This area corresponds to the buffer zones shown in Fig. 3 for this city. They concluded that about $9 \%$ of the area revealed increase in vegetation cover in response to climate warming while $10.8 \%$ of the area had decrease in vegetation cover due to the infrastructure development and related factors (logging, tracking etc). The direct mechanical impact on the vegetation cover was very localized (mostly within $100 \mathrm{~m}$ from the infrastructural objects), but indirect biophysical impacts, such as changes in the surface hydrology, heat balance and ecosystem damages (e.g. fires) were found over significantly larger areas. These wider indirect impacts of urbanization are visible not only in highly aggregated analysis in the present study but also in plot-scale experiments. The global warming favors expansion of wood vegetation over the permafrost. However, the mechanical removal of shrubs in a Siberian tundra site initiated permafrost thaw converting the plot into waterlogged depression within 5 years (Nauta et al., 2015). Thus, there seems to be a concert between the impacts on vegetation cover and the soil cryosphere induced by global warming and anthropogenic disturbances.

\section{Conclusions}

This study presented the NDVImax analysis of the MODIS NDVI data product MOD13Q1 with $250 \mathrm{~m}$ spatial resolution over 2000-2014. We obtained the maps of NDVImax and NDVImax trends for the northern West Siberia region where intensive oil and gas exploration created a large number of anthropogenic disturbances. These new maps were discussed in the context of the previously published lowand high-resolution NDVI analysis available for this region. The obtained NDVImax trends are highly fragmented, but confirm the observed dichotomy of northern greening (the increasing vegetation productivity) versus southern browning (the decreasing productivity). The statistically significant NDVImax trends occupy only a small fraction of NWS. The 
most significant trends are found on the territories with sandy soils and with larger concentration of soil disturbances. Thus, the new map substantially corrects the previous picture of the vegetation cover changes in NWS and suggests stronger resilience of undisturbed vegetation cover to the climate change on decadal timescales.

It has been proposed that the disturbances might help to establish alternative, more productive vegetation cover. We used NDVImax data in and around 28 regional urbanized and industrial areas to compare the vegetation productivity of the reclaiming and background plant communities across all four major biomes. We assumed growing concentration of disturbances towards the city cores. The results indicated that the reclaiming plant communities tend to be more productive. Only some cities in middle taiga biome, notably the largest cities of Surgut and Niznevartovsk on the Ob river, exhibit lower productivity in the closest city proximity.

As it was expected, we found NDVImax at the city cores to be 15 to $40 \%$ lower than over the corresponding background. At the same time, many cities have become significantly greener over the analyzed 15 years. This tendency reflects both the targeted efforts to create more environmentally friendly residential areas and the urban heat island impact on the active soil layer thickness and drainage.

\section{Data availability}

MOD13Q1 data are freely available from https: //lpdaac.usgs.gov/dataset_discovery/modis/modis_ products_table/mod13q1 (last checked on 27 July 2016) and https://daac.ornl.gov/MODIS/MODIS-menu/modis_ webservice.html (last checked on 27 July 2016). The processed data for this study are stored in MS EXEL files. At present they are available from the corresponding author by e-mail request. All data and processed images will be made publicly available at the project web site http://hiarc.nersc.no and through the ResearchGate (www.researchgate.net) after the end of the HIARC project. 


\section{Appendix A: Statistical significance of inter-city analysis}

The NDVImax data in and around the cities are very variable. In order to estimate the statistical significance of the difference of multiple time series, we used a conservative hypothesis testing with the Student's $t$-criterion. In this analysis, two statistical parameters are different at the confidence level $95 \%(\alpha=1.96$, the light gray shading in Figs. 3 and 4) and $99 \%$ ( $\alpha=2.58$, the dark gray shading) assuming the normal distribution of the difference errors when

$\sqrt{\frac{2}{N-1}(\sigma(k, n))}>\alpha$,

where $\sigma(k, n)$ is the standard deviation of a parameter in testing for the ring $k$ and the city $n$. We want to stress that the conservative estimation is related to the differences, which have significantly larger magnitude than the variations of NDVImax within each ring. Thus, the differences appear to be more significant than the trends for each of the rings. There were found no significant trends at levels higher than $90 \%$ for any $5-\mathrm{km}$ ring around any city. 
Acknowledgements. This study was supported by (1) the Belmont Forum and the Norwegian Research Council grant HIARC: Anthropogenic Heat Islands in the Arctic: Windows to the Future of the Regional Climates, Ecosystems, and Societies (no. 247268), (2) the Belmont Forum and the U.S. National Science Foundation grant Collaborative Research: HIARC: Anthropogenic Heat Islands in the Arctic: Windows to the Future of the Regional Climates, Ecosystems, and Societies (no. 1535845), and (3) the Centre for Climate Dynamics grant BASIC: Boundary Layers in the Arctic Atmosphere, Seas and Ice Dynamics.

Edited by: V.-M. Kerminen

Reviewed by: A. Colpaert and one anonymous referee

\section{References}

Archegova, I. B.: Thermal regime of tundra soils under reclamation and restoration of natural vegetation, Eurasian Soil Sci+., 40, 854-859, 2007.

Barichivich, J., Briffa, K. R., Myneni, R., van der Schrier, G., Dorigo, W., Tucker, C. J., Osborn, T. J., and Melvin, T. M.: Temperature and snow-mediated moisture controls of summer photosynthetic activity in northern terrestrial ecosystems between 1982 and 2011, Remote Sens., 6, 1390-1431, 2014.

Beck, P. and Goetz, S.: Satellite observations of high northern latitude vegetation productivity changes between 1982 and 2008: ecological variability and regional differences, Environ. Res. Lett., 6, 045501, doi:10.1088/1748-9326/6/4/045501, 2011.

Bhatt, U. S., Walker, D. A., Raynolds, M. K., Bieniek, P. A., Epstein, H. E., Comiso, J. C., Pinzon, J. E., Tucker, C. J., and Polyakov, I. V.: Recent declines in warming and vegetation greening trends over pan-Arctic tundra, Remote Sens., 5, 42294254, 2013.

Brunsell, N. A., Mechem, D. B., and Anderson, M. C.: Surface heterogeneity impacts on boundary layer dynamics via energy balance partitioning, Atmos. Chem. Phys., 11, 3403-3416, doi:10.5194/acp-11-3403-2011, 2011.

Bulygina, O., Groisman, P. Y., Razuvaev, V., and Korshunova, N.,: Changes in snow cover characteristics over Northern Eurasia since 1966, Environ. Res. Lett., 6, 045204, doi:10.1088/17489326/6/4/045204, 2011.

Bunn, A. and Goetz, S.: Trends in Satellite-Observed Circumpolar Photosynthetic Activity from 1982 to 2003: The influence of seasonality, cover type, and vegetation density, Earth Interact., 10, 1-19, 2006

Cohen, J. L., Furtado, J. C., Barlow, M. A., Alexeev, V. A., and Cherry, J. E.: Arctic warming, increasing snow cover and widespread boreal winter cooling, Environ. Res. Lett., 7, 014007 , doi:10.1088/1748-9326/7/1/014007, 2012.

d'Arrigo, R. D., Malmstrom, C. M., Jacoby, G. C., Los, S. O., and Bunker, D. E.: Correlation between maximum latewood density of annual tree rings and NDVI based estimates of forest productivity, Int. J. Remote Sens., 21, 2329-2336, 2000.

Devi, N., Hagedorn, F., Moiseev, P., Bugmann, H., Shiyatov, S., Mazepa, V., and Rigling, R.: Expanding forests and changing growth forms of Siberian larch at the Polar Urals treeline during the 20th century, Glob. Change Biol., 14, 1581-1591, 2008.
Elmendorf, S. C., Henry, G. H. R., Hollister, R. D., Björk, R. G., Boulanger-Lapointe, N., Cooper, E. J., Cornelissen, J. H. C., Day, T. A., Dorrepaal, E., Elumeeva, T. G., Gill, M., Gould, W. A., Harte, J., Hik, D. S., Hofgaard, A., Johnson, D. R., Johnstone, J. F., Jónsdóttir, I. S., Jorgenson, J. C., Klanderud, K., Klein, J. A., Koh, S., Kudo, G., Lara, M., Lévesque, E., Magnússon, B., May, J. L., Mercado-Diaz, J. A., Michelsen, A., Molau, U., Myers-Smith, I. H., Oberbauer, S. F., Onipchenko, V. G., Rixen, C., Schmidt, N. M., Shaver, G. R., Spasojevic, M. J., Bórhallsdóttir, B. E., Tolvanen, A., Troxler, T., Tweedie, C. E., Villareal, S., Wahren, C.-H., Walker, X., Webber, P. J., Welker, J. M., and Wipf, S.: Plot-scale evidence of tundra vegetation change and links to recent summer warming, Nature Climate Change, 2, 453-457, 2012.

Elsakov, V. and Teljatnikov, M.: Effects of interannual climatic fluctuations of the last decade on NDVI in north-eastern European Russia and Western Siberia, Contemporary Problems of the Earth's Remote Sensing, 10, 260-271, 2013.

Epstein, H. E., Raynolds, M. K., Walker, D. A., Bhatt, U. S., Tucker, C. J., and Pinzon, J. E.: Dynamics of aboveground phytomass of the circumpolar Arctic tundra during the past three decades, Environ. Res. Lett., 7, 015506, doi:10.1088/1748-9326/7/1/015506, 2012.

Esau, I., Davy, R., and Outten, S.: Complementary explanation of temperature response in the lower atmosphere, Environ. Res. Lett., 7, 044026, doi:10.1088/1748-9326/7/4/044026, 2012.

Frey, K. and Smith, L.: How well do we know northern land cover: Comparison of four global vegetation and wetland products with a new ground-truth database for West Siberia, Global Biogeochem. Cy., 21, GB1016, doi:10.1029/2006GB002706, 2007.

Frost, G., Epstein, H., Walker, D., Matyshak, G., and Ermokhina, K.: Patterned-ground facilitates shrub expansion in Low Arctic tundra, Environ. Res. Lett., 8, 015035, doi:10.1088/17489326/8/1/015035, 2013.

Frost, G. V. and Epstein, H. E.: Tall shrub and tree expansion in Siberian tundra ecotones since the 1960s, Glob. Change Biol., 20, 1264-1277, 2014.

Goetz, S. J., Bunn, A. G., Fiske, G. J., and Houghton, R. A.: Satellite-observed photosynthetic trends across boreal North America associated with climate and fire disturbance, Proc. Natl. Acad. Sci. USA, 102, 13521-13525, 2005.

Guay, K., Beck, P., Berner, L., Goetz, S., Baccini, A., and Buermann, W.: Vegetation productivity patterns at high northern latitudes: a multi-sensor satellite data assessment, Glob. Change Biol.y, 20, 3147-3158, 2014.

Croisman, P. and Gutman, G. (Eds.): Environmental changes in Siberia: Regional changes and their consequences, Springer, Amsterdam, 2013.

Hicks Pries, C. E. H., Schuur, E. A. G., Vogel, J. G., and Natali, S. M.: Moisture drives surface decomposition in thawing tundra, J. Geophys. Res. Biogeosci., 118, 1133-1143, 2013.

Hinzman, L. D., Bettez, N. D., Bolton, W. R., et al.: Evidence and implications of recent climate change in northern Alaska and other Arctic regions, Clim. Change, 72, 251-298, 2005.

Ippolitov, I. I., Loginov, S. V., Kharyutkina, E. V., and Moraru, E. I.: Climate variability over the Asian territory of Russia during 1975-2012, Geography and Natural Resources, 35, 310-318, 2014. 
Jeong, J.-H., Kug, J.-S., Kim, B.-M., Min, S.-K., Linderholm, H. W., Ho, C.-H., Rayner, D., Chen, D., and Jun, S.-Y.: Greening in the circumpolar high-latitude may amplify warming in the growing season, Clim. Dynam., 38, 1421-1431, 2011.

Juszak, I., Eugster, W., Heijmans, M. M. P. D., and SchaepmanStrub, G.: Contrasting radiation and soil heat fluxes in Arctic shrub and wet sedge tundra, Biogeosciences Discuss., doi:10.5194/bg-2016-41, in review, 2016.

Keeling, C. D., Chin, J. F. S., and Whorf, T. P.: Increased activity of northern vegetation inferred from atmospheric $\mathrm{CO}_{2}$ measurements, Nature, 382, 146-149, 1996.

Kornienko, S. and Yakubson, K.: A study of transformation of vegetation cover in over some areas of Taz peninsula using satellite imagery, Arctic: Ecology and Economics, 4, 46-57, 2011.

Koronatova, N. and Milyaeva, E.: Plant community succession in post-mined quarries in the northern-taiga zone of West Siberia, Contemp. Probl. Ecol., 4, 513-518, 2011.

Kumpula, T., Pajunen, A., Kaarlejarvi, E., Forbes, B. C., and Stammler, F.: Land use and land cover change in Arctic Russia: Ecological and social implications of industrial development, Global. Environ. Chang., 21, 550-562, 2011.

Kumpula, T., Forbes, F., Stammler, F., and Meschtyb, N.: Dynamics of a coupled system: Multi-resolution remote sensing in assessing social-ecological responses during 25 years of gas field development in Arctic Russia, Remote Sens., 4, 1046-1068, 2012.

Lapenis, A., Shvidenko, A., Shepaschenko, D., Nilsson, S., and Aiyyer, A.: Acclimation of Russian forests to recent changes in climate, Glob. Change Biol., 11, 2090-2102, 2005.

Leibman, M., Khomutov, A., Gubarkov, A., Mullanurov, D., and Dvornikov, Y.: The research station "Vaskiny Dachi", Central Yamal, West Siberia, Russia - A review of 25 years of permafrost studies, Fennia, 193, 3-30, 2015.

Lloyd, A. and Bunn, A.: Responses of the circumpolar boreal forest to 20th century climate variability, Environ. Res. Lett., 2, 045013, doi:10.1088/1748-9326/2/4/045013, 2007.

Lloyd, A., Yoshikawa, K., Fastie, C. L., Hinzman, L., and Fraver, M.: Effects of permafrost degradation on woody vegetation at arctic treeline on the Seward Peninsula, Alaska, Permafrost Periglac., 14, 93-101, 2003.

MacDonald, G., Kremenetski, K., and Beilman, D.: Climate change and the northern Russian treeline zone, Phil. Trans. Roy. Soc. B, 363, 2283-2299, 2008.

Macias-Fauria, M., Forbes, B., Zetterberg, P., and Kumpula, T.: Eurasian Arctic greening reveals teleconnections, Nature Climate Change, 2, 613-618, 2012.

Melnikov, E. S., Leibman, M. O., Moskalenko, N. G., and Vasiliev, A. A.: Active-layer monitoring in the cryolithozone of West Siberia, Polar Geography, 28, 267-285, 2004.

Moskalenko, N.: Impact of climate warming on vegetation cover and permafrost in West Siberia northern taiga, Natural Science, 5, 144-148, 2013.

Myneni, R. B., Keeling, C. D., Tucker, C. J., Asrar, G., and Nemani, R. R.: Increased plant growth in the northern high latitudes from 1981 to 1991, Nature, 386, 698-702, 1997.

Nauta, A. L., Heijmans, M., Blok, D., Limpens, J., Elberling, B., Gallagher, A., Li, B., Petrov, R. E., Maximov, T. C., van Huissteden, J., and Berendse, F.: Permafrost collapse after shrub removal shifts tundra ecosystem to a methane source, Nature Climate Change, 5, 67-70, 2015.
Outten, S. and Esau, I.: A link between Arctic sea ice and recent cooling trends over Eurasia, Climatic Change, 110, 1069-1075, 2011.

Outten, S., Davy, R., and Esau, I.: Eurasian winter cooling: Intercomparison of Reanalyses and CMIP5 data sets, Atmos. Ocean. Sci. Lett., 6, 324-331, 2013.

Pavlov, A. V. and Moskalenko, N. G.: The thermal regime of soils in the north of Western Siberia, Permafrost Periglac., 13, 43-51, 2002.

Raynolds, M. K., Walker, D. A., Epstein, H. E., Pinzon, J. E., and Tucker, C. J.: A new estimate of tundra-biome phytomass from trans-Arctic field data and AVHRR NDVI, Remote Sens. Lett., 3, 403-411, 2012.

Raynolds, M. K., Walker, D. A., Ambrosius, K. J., Brown, J., Everett, K. R., Kanevskiy, M., Kofinas, G. P., Romanovsky, V. E., Shur, Y., and Webber, P. J.: Cumulative geoecological effects of 62 years of infrastructure and climate change in ice-rich permafrost landscapes, Prudhoe Bay Oilfield, Alaska, Glob. Change Biol., 20, 1211-1224, 2014.

Shulgina, T., Genina, E., and Gordov, E.: Dynamics of climatic characteristics influencing vegetation in Siberia, Environ. Res. Lett., 6, 045210, doi:10.1088/1748-9326/6/4/045210, 2011.

Shuman, J. K. and Shugart, H. H.: Evaluating the sensitivity of Eurasian forest biomass to climate change using a dynamic vegetation model, Environ. Res. Lett., 4, 045024, doi:10.1088/17489326/4/4/045024, 2009.

Solano, R., Didan, K., Jacobson, A., and Huete, A.: MODIS Vegetation Index User's Guide (MOD13 Series), 2010, available at: http://vip.arizona.edu, last access: 27 July 2016.

Sorokina, N.: Anthropological changes in the northern taiga ecosystems of West Siberia (Nadym area), PhD thesis, Institute for the Earth's Cryosphere, 2003

Streletskiy, D., Shiklomanov, N., and Nelson, F.: Permafrost, infrastructure, and climate change: a GIS-based landscape approach to geotechnical modeling, Arct. Antarct. Alp. Res., 44, 368-380, 2012.

Sturm, M., McFadden, J., Liston II, G. F. C., Racine, C., and Holmgren, J.: Snow-shrub Interactions in Arctic tundra: A hypothesis with climatic implications, J. Climate, 14, 336-343, 2001.

Urban, M., Forkel, M., Eberle, J., Hüttich, C., Schmullius, C., and Herold, M.: Pan-Arctic climate and land cover trends derived from multi-variate and multi-scale analyses (1981-2012), Remote Sens., 6, 2296-2316, 2014.

Tang, Q. and Leng, G.: Damper summer warming accompanied with cloud cover increase over Eurasia from 1982 to 2009, Environ. Res. Lett., 7, 014004, doi:10.1088/1748-9326/7/1/014004, 2012.

Walker, D., Leibman, M., Epstein, H., Forbes, B., Bhatt, U., Raynolds, M., Comiso, J., Gubarkov, A., Khomutov, A., Jia, G., Kaarlejarvi, E., Kaplan, J., Kumpula, T., Kuss, P., Matyshak, G., Moskalenko, N., Orekhov, P., Romanovsky, V., Ukraientseva, N., and Yu, Q.: Spatial and temporal patterns of greenness on the Yamal Peninsula, Russia: interactions of ecological and social factors affecting the Arctic normalized difference vegetation index, Environ. Res. Lett., 4, 045004, doi:10.1088/17489326/4/4/045004, 2009.

Walker, M., Wahren, C., Hollister, R., Henryd, G., Ahlquist, L., Alatalo, J., Bret-Harte, M., Calef, M., Callaghan, T., Carroll, A., Epstein, H., Jonsdottir, I., Klein, J., Magnusson, B., Molau, U., 
Oberbauer, S., Rewa, S., Robinson, C., Shaver, G., Suding, K., Thompson, C., Tolvanen, A., Totland, Ø, Turner, P. L., Tweedie, C., Webber, P., and Wookey, P.: Plant community responses to experimental warming across the turndra biome, Proc. Natl. Acad. Sci., 5, 1342-1346, 2006.

Yakubson, K., Kornienko, S., Razumov, S., Dubrovin, V., Kritsuk, L., and Yastreba, N.: Geoindicators of the environmental change in areas of intensive oil and gas development and methods of their evaluation, Georesources, Geoenergetics, Geopolitics, 2, 122, available at: http://oilgasjournal.ru/vol_6/kornienko.swf (last access: 27 July 2016), 2012.

Yu, Q., Epstein, H. E., Engstrom, R., Shiklomanov, N., and Strelestskiy, D.: Land cover and land use changes in the oil and gas regions of Northwestern Siberia under changing climatic conditions, Environ. Res. Lett., 10, 124020, doi:10.1088/17489326/10/12/124020, 2015.
Zhang, X., Friedl, M. A., Schaaf, C. B., Strahler, A. H., and Schneider, A.: The footprint of urban climates on vegetation phenology, Geophys. Res. Lett., 31, L12209, doi:10.1029/2004GL020137, 2004.

Zhao, T., Bergen, K., Brown, D., and Shugart, H.: Scale dependence in quantification of land-cover and biomass change over Siberian boreal forest landscapes, Landscape Ecol., 24, 1299-1313, 2009.

Zhou, L., Tucker, C., Kaufmann, R., and Slayback, D.: Variations in northern vegetation activity inferred from satellite data of vegetation index during 1981 to 1999, J. Geophys. Res., 106, 2006920083, 2001 